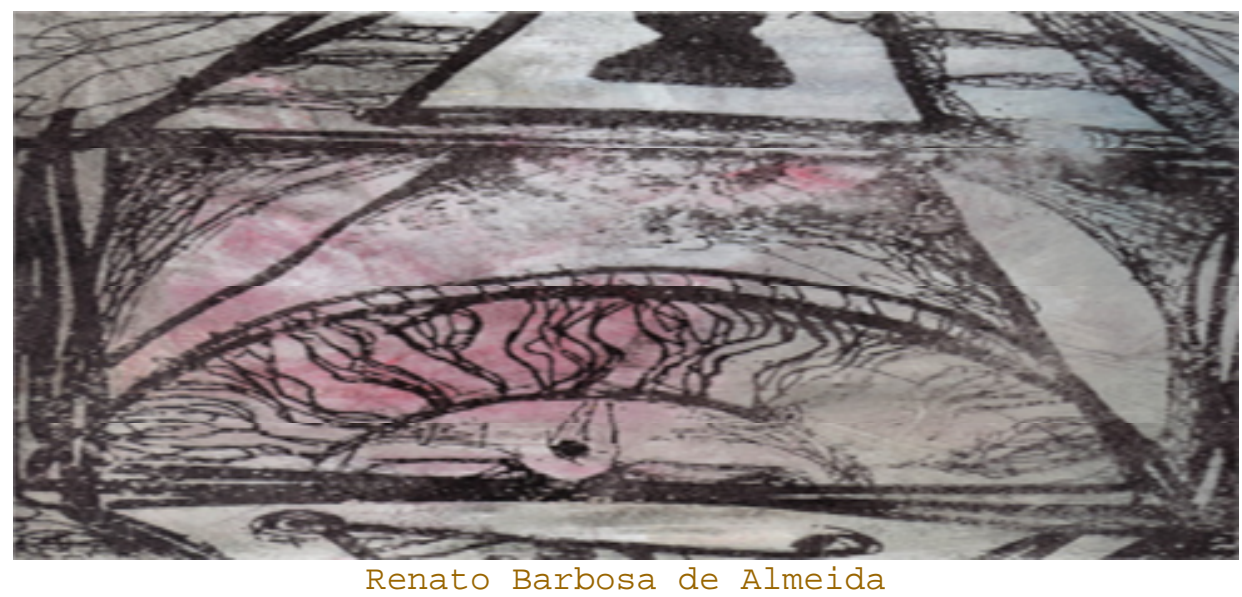

\title{
21 desconselhos para quem quer conhecer a Arte de desLER e desAPRENDER
}

\section{Ronald Claver}

1. Leia o texto, primeiramente, em voz alta.

2. Leia uma frase saltando sempre uma palavra.

3. Leia o texto saltando sempre uma frase de forma intercalada.

4. Leia o silêncio que há entre uma palavra e outra.

5. Leia as entrelinhas.

6. Leia sempre o contrário. Se existir um NÃO, substitua por um SIM.

7. Escreva todas as palavras que te metem medo.

8. Escreva os palavrões mais cabeludos e depois jogue-os fora.

9. Escreva seus desejos inconfessáveis, depois mande-os para o limbo.

10. Descreva uma cena de sexo violento, bizarro e não importe com a avaliação de sua família e vizinhos.

11. Assuma o papel dos personagens com coragem. Se for um cego, tateie. Se for homem, vire homem, se for peixe, nade. Se for aranha, teça.. Se crente, creia. Se revolucionário, atire. 
12. Seja cruel ao descrever qualquer cena. Abuse dos termos "proibidos".

13. Olhe ao redor. As coisas estão vivas. Querem você. Escuteas. Tenha paciência. Um dia seu texto aflora.

14. Olhe no espelho. Verifique se suas coisas estão no lugar. Se há dedos em suas mãos. Se há duas orelhas. Uma boca. Se os olhos ainda piscam. Reveja seus escritos antigos. Note se há palavras em excesso ou se há falta delas.

15. Desaprenda toda ciência herdada, adquirida e tente entender o barulho das pedras, o silêncio dos relâmpagos, a rapidez de uma tartaruga.

16. Esqueça seus valores, sua cultura, sua religião e conviva com os mendigos e escreva sobre a ronda noturna de um viralata.

17. Tire o terno, raspe o cabelo, ponha um bigode falso e use um boné vermelho. Tente entrar em sua empresa, sem ser barrado. Quais as palavras que serão utilizadas para convencer 0 segurança?

18. Toda história de amor é sempre uma história de amor, então convença o seu não-amor com novas palavras de amor e morte.

19. Tire os óculos. Lave os olhos. Abra os olhos e veja as pessoas conhecidas como se fossem desconhecidas. Tente um diálogo com elas.

20. Valorize as pequenas coisas. Um papel de bala, o olhar pedinte do cachorro, uma lua nada cheia, a moça suburbana de roupa de chita e sorriso guloso, o rapaz que olha para frente sem perspectiva, a solteirona e suas esquisitices, a mãe que espera o filho madrugada afora, o poema que resiste à palavra, a notícia velha forrando o chão do boteco, o político quase honesto, os etceteras das esquinas. Faça um diário relatando estas pequenas e surpreendentes epifanias.

21. Não espere a inspiração. Corra atrás dela. Invente palavras. Beijos. Desejos. Cartas. Viva o seu mundo interior intensamente e dê uma banana para a mesmice, escreva, escreva, sem censura. Esqueça o que seu marido vai achar de sua história. O seu pai não tem que achar nada, nem seu vizinho. Você é que deve avaliar se o seu texto é mesmo seu ou você faz concessão para não desagradar os outros. Quem manda em seu texto é você e suas palavras. Desleia sempre e continue desaprendendo per omnia secula seculorum, amen. 